\title{
Research on Calculation Method for Agricultural Informatization Contribution Rate
}

\author{
Liyong Liu ${ }^{1}$, Qilong Pan $^{2}$, and Daoliang $\mathrm{Li}^{1, *}$ \\ ${ }^{1}$ College of Information and Electrical Engineering, China Agricultural University, \\ 17 Tsinghua East Road, P.O. Box 121, Beijing, 100083, P.R. China \\ 1i_daoliang@yaohoo.com \\ ${ }^{2}$ College of Agricultural Economics and Rural Development, \\ Renmin University of China, P.R. China 100872
}

\begin{abstract}
Informationization is the development trend around the world. In terms of agriculture, it is informationization that the Chinese government takes as a significant strategy in order to solve the 'agriculture, farmer and village' problem. Focusing on how to measure the contribution of agricultural informationization to economic growth, this paper explores several key issues in current literatures and summarizes the latest debates in respects of the concept of agricultural informationization, the evaluation method of agricultural informatization, and the calculation method of contribution rate of agricultural informationization to economic growth. This paper finally argues that further research is urgently needed for the contribution rate of agricultural informationization to economic growth due to the existing literature gap regarding the research scope, calculation method, informationization's impact on agriculture itself, and the practice.
\end{abstract}

Keywords: agricultural informatization, contribution rate, index system, calculation.

\section{Introduction}

Agricultural informatization contribution rate refers to the proportion of algebraic summation in agricultural informatization contributed to in various production elements, or refers to the proportion of role played by agricultural informatization to the agricultural economic growth, and total agricultural output or total value of farm out-put are often used to state agricultural economy level. Agricultural informatization contribution rate will be an important comprehensive index that reflected agricultural informatization's function and role in agricultural production efficiency growth and agricultural economic development, and will also be an important index that reflected agricultural production mode and production level. Agricultural informatization contribution rate is still a new concept. Through consulting relevant literature in China and abroad, "informatization contribution rate ", Agricultural informatization contribution rate and their

Corresponding author. Tel.: +86-10-62736764; Fax: +86-10-62737741. 
theoretical frontiers for calculation could be grasped well, and it is of great significance to understand scientifically agricultural informatization contribution rate and to further explore the calculation method which suits Chinese condition well.

There are several key problems needing to be solved when researching calculation method of agricultural informationization contribution rate. The first one is the definition of the concept and category of informatization and agricultural informatization. The second is measurement method of informatization and agricultural informatization level. The third one is measurement methods of the contribution rate of informatization to economic growth. The last one is the application of all measurement methods in agricultural informatization contribution rate. There has been much research on the aspects mentioned above, which provides study foundation for further work. So this paper mainly focuses on the summary and analysis of relevant literature in China and abroad.

\section{Research about the Concept and Connotation of Agricultural Informatization}

For the concept of the agricultural informatization, there has not been made an authoritative explanation in theory. Chunjiang Zhao (2007) pointed out that agricultural informatization is a process, which, in human agricultural production activities and social practice, promotes agricultural economy development and the rural social progress by way of high-tech such as communications technology and information technology to efficiently make use of information resources. Shihong Liu (2005) pointed out agricultural informatization is a rural and agricultural integrated system including agricultural resources and environment informatization, rural social and economic informatization, agricultural production informatization, agricultural science and technology informatization, rural education informatization and agricultural production material and production management informatization. Fangquan Mei (2007) thinked agricultural informatization is a generalized concept, which is the wide application of information technology and information management in rural areas and should be informatization of agricultural overall process, and at least six fields, those are the informatization of rural life and consumption, the informationization of agricultural production management, the informationization of rural science and technology, the informationization of rural operation and management, the informatization of rural market circulation, and the informatization of rural resources and environment, should be included. Based on former research and some relevant conclusion, Daoliang $\mathrm{Li}$ (2008) and his team, make agricultural informatization as following definition: Agricultual informationization refers to a degree and process which modern information technology can be applied in rural production and business operation, rural public service, government management and daily consumption and other aspects through enhancing rural information infrastructure construction, such as broadcast networks, telecommunication network and computer network, fully developing and utilizing of information resources, structuring information service system, promoting information communication and knowledge sharing. 


\section{Research on Agricultural Informatization Level Measurement}

It is very different about the period, ways, speed and types of agricultural informatization around the world. In developed countries, study on agricultural informatization level measurement earlier was proceeded very early and have formed several mature development systems, which includs evaluation system. In the middle of 1980s, UNESCO proposed to use information utilization potential index method, and have done some practical measurement research (BroklH,Menou M.J. ,1982). In 1982, America's B.K. Eers used three-factors multiple-parameter model to analyze 87 underdeveloped countries' correlation of information activities with the social and economic development (Eres B k. 1982). Vijay S and William R K (1994) started wiht obtaining the competitive advantage and proposed evaluation index system of the enterprise's informatization, which included seven factors, totally twenty-nine indices. Ravi (1999) et al. started with keeping the competitive position and proposed to use 15 2nd indices to subdivide 1 st index (key competition point) and to evaluate the enterprise informatization. In order to evaluate enterprise informatization from the angle realizing the strategic objectives, Nagalingam (1997) used multiple-target comprehensive evaluation method and divided every strategic objective into several operational sub-objectives, which formed evaluation index system to be used in expert system. Under the condition of keeping China national informatization index system and Beijing informatization statistic index system identical and according to information basic elements and principles to establish evaluation index system, Anxiang Lu, Yunlong Zhao, Xiangyang Qin, Zhihong Ma （2006） et al. proposed six aspects, from information resources development, informatization talents, construction of information network, application of information technology, consumptive level of information, and development level of information industry, including 19 indices to evaluate of rural informatization ( Table 1).

Table 1. Agricultural informatization level evaluation index system (Anxiang Lu, et al. 2006)

\begin{tabular}{clc}
\hline No. & \multicolumn{1}{c}{ Index } & Unit \\
\hline 1 & Average hours radio and television broadcast per day & Hours/day \\
2 & Internet users per ten thousands person & Families/ 10000 \\
& & persons \\
3 & bandwidth possession Per capita & $\mathrm{KB} /$ person \\
4 & quantity of university students per ten thousands person & Persons/ ten thousands \\
& & person \\
5 & Computer ownership rate per 100 Family & Sets/100 Family \\
6 & Lines of main toll route per 100 persons for fixed telephones & Lines/100 Family \\
7 & quantity of mobile phones per hundred person & Sets/100 person \\
8 & Rate of cable TV to premises & $\%$ \\
9 & The village owning cable rate (rate of the optical fibre cable to & $\%$ \\
& village) & $\%$ \\
10 & Broadband households rate(rate of broadband to premises) & $\%$ \\
11 & Information index & $\%$ \\
\hline
\end{tabular}


Table 1. (continued)

\begin{tabular}{llc}
\hline 12 & $\begin{array}{l}\text { Quantity of computer per hundred students, including college, } \\
\text { middle school student }\end{array}$ & Sets/100 person \\
13 & $\begin{array}{l}\text { Proportion of enterprises using internet enterprises to total } \\
\text { enterprises }\end{array}$ & $\%$ \\
14 & $\begin{array}{l}\text { Cable's length per } 100 \text { square kilometers } \\
15\end{array}$ & $\begin{array}{c}\text { Core kilometers } \\
\text { total capacity of network resource database }\end{array}$ \\
16 & E-commerce transaction rate & $\%$ \\
17 & Rate of Information industry added-value to GDP \\
18 & $\begin{array}{l}\text { proportion of fixed investment in information industry to fixed } \\
\text { investment in whole society }\end{array}$ & $\%$ \\
19 & $\begin{array}{l}\text { Proportion of the expenses for information industry research and } \\
\text { development to the expenses for whole social research and } \\
\text { development }\end{array}$ & $\%$ \\
\hline
\end{tabular}

\section{The Study of Calculation Methods of Informatization Contribution Rate to Economic Growth}

The theory of informatization measurement was originally proposed by American economists Fritz Machlup in his American Knowledge Production and Distribution in 1962. This measureing method is very wide, all-embracing in range, involving in various fields of intellectual industry. On the basis of Machlup, M. Poratm in 1977 put forward a new method system which is operative. The theory thinks that the development of information economy mainly depends on the development of two great information departments. The first department is that directly produces information and knowledge and then processes it. The second department is that consume information, namely all the the governments consuming information service and non-information enterprise. M. Poratm thought that the second information department plays an important role in information economy. For information economic input-output analysis, M. Poratm put forward a set of theories and methods of compiling information input-output table according to general input-output data, and used US national statistic data to concretely measure the employment and GNP value of information economy in US, which firstly makes people have a clear understanding to America's economic structure and nature.

Japanese economists Komatsu Kiyoshi in 1965 put forward informatization index method. This informatization index model is composed of 4 second indices and 11 third indices, including information amount (indirectly to show information equipment level and development level of information services' industry), information equipment rate, communication body level (personnel structure and the third industry development level), information coefficient (consumer's input besides the basic living expenses) and so on. This method is simple and easy to operate and has been widely used in many countries including China. 
Compared with the developed countries, it is very late in China to study informationization. In the middle of 1980s China began to research on information theory and informatization level measure theory and methods. In 1997 Informationization Work Leading Group of the State Council put forward the definition of national informatization firstly.

When measuring informatization level in China, combining with China's specific situation and fully absorbing foreign existing scientific evaluation methods, Chinese scholars put forward some Chinese characteristic calculation methods of information contribution rate to economic growth. Youping Zhu (1996) used C-D Function to carry out regression analysis with Chinese real GDP data from 1980 to 1992 and information, capital and labor elements. The results showed that the information elements' contribution is the highest to the national economic growth (coefficient is 0.841597), the following one is labor elements (coefficient is 0.697838), and the last is the capital (coefficient is 0.255566). Based on output-growth production function, Dongqiang Guo, Zhijiang Wang (2000) put forward a mathematic model, which can measure contribution rate of informatization input to enterprise output growth, and provide theory basis for the quantitative evaluation of enterprise informatization's construction. According to Cobb-Douglas production function, Hua Zhou (2009) constructed a production function model which based on the informatization input. He took 54 electrical manufacturing enterprises informationization data in Fujian province from 2004 to 2006 as sample, and applied panel data analysis method to measure the output contribution coefficient of informatization.

\section{Research on Measuring Method of Agricultural Informatization Contribution Rate}

Although there is amount of research in the measurement of contribution rate of informatization to economic growth in China and abroad, which accumulated much theory and a number of methods, and provides important reference for further research, From literature retrieval there is no statement of Agricultural informatization contribution rate up to now and study on contribution of agricultural informatization to agricultural economic growth is also very little. Xinran Zhao (2006) did a preliminary discussion of agricultural informatization input and output by way of cobb-douglas production function method in her master thesis, And the evaluation index of contribution of information input to agricultural economic growth was calculated by using the result of regression analysis.

Whether for the establishment of agricultural informatization evaluation system, or for construction of C-D production function, the argumentation for variable selection is still insufficient, leading to the lack of scientificity in conclusion and the vagueness of the concept of agricultural informatization. In addition, there is no directly relevant literature about agricultural informatization contribution rate. It is obviously a new research field to study the calculation method of agricultural informatization contribution rate. 


\section{Conclusion}

To sum up, agricultural informatization contribution rate, as a comprehensive index reflecting the function of agricultural informatization in agricultural production efficiency and agricultural economic growth,, is still a new concept in academia. There is few direct research literature, and the research on theory and method is very short. But there is amount of research focusing on the informatization and measurement of agricultural informatization level, contribution rate of informatization to economic growth, which provide great foundation and many references to further study in theories and methods. Nonetheless, in those studies, there are still some problems needing to be solved. It is mainly in the following respects.

(1) As for the definition and concept of informationization, many definitions are basically limited to country, region. There are almost no statements on agricultural informatization or rural informatization abroad and most research are about the application of information technology in agriculture. Agricultural and rural informationization is an unique vocabulary under existing situation in China. The research scope of agricultural informatization is broad with different versions. Therefore, the principal task of research on agricultural informatization contribution rate is to clear the concept, connotation and extension of agricultural informatization based on the theory and practice in China and abroad.

(2) Although in the world there are dozens of methods of the informatization level measurement and analysis, the more common methods are Porat's method and the social informatization index model suggested by Japanese scholar, and both of them have their own advantages and disadvantages. Porat's method is a macro measure way, fitting for a national and social informatization, but it is not fit for agricultural informatization level measuring, because in China the concept of agricultural information industry is not clear. Japanese informatization index model neglectes the function of knowledge production department and information production department, which are very crucial in Porat's method. Informatization index method uses arithmetic average, which covers up some substantive difference. With the development of the times, the indices have seriously outdated, being hard to reflect the development trend and the latest achievements in informatization. In future, the research on index selection of agricultural informatization level measurement must fully consider the modern information technology development situation, such as the agricultural information technology application and promotion, etc.

(3) In the impact of informatization on economic and social development, existing research mainly concentrated on the impact of informatization on national economy, the difference of informatization level and informatization contribution rate between different countries, enterprise informatization and its benefit, etc. The research of contribution of informatization on agricultural development is very pool. Especially there are few studies on contribution rate of different informatization indices to agricultural development, leading to the shortage of scientific guidance when evaluating the efficiency of agricultural informatization construction.

(4) In the aspects of agricultural informatization level measurement and informatization contribution rate, most studies didn't deeply analyze the relationship and 
reciprocal influence between the informationization level and the efficiency difference, and couldn't provide feasible suggestions for national strategy and policies or measures. When trying to measure the contribution rate of agricultural informatization, it should pay much attention to the practical operation of informatization construction in future research.

\section{Acknowledgements}

The authors thank Ministry of Agriculture of People's Republic of China for it's financial support.

\section{References}

[1] Brokl,H., Menou, M.J., Index of information Utilization Potential. Final Report of Phase 2 of the IUP Pilot Porject. GSLIS/UCLA, LosAngeles (1982)

[2] Eres, B.K.: Economic conditions report to informationactivity in less developed countries.

[3] Nagalingam, S.V., Lin, G.C.I.: A unified approach towards CIM justification. Computer Integrated Manufac-turing Systems 2, 133-145 (1997)

[4] Ravi, K., Murugan, A., Magid, I.: Selecting IT applications inmanufacturing: aKBS approach. Omega 27(2), 605-616 (1999)

[5] Vijay, S., William, R.K.: Development of measures to as-sess the extent towhich an information technology appli-cation provides competitive advantage. Management Science (12), 1601-1627 (1994)

[6] Guo, D.Q., Wang, Z.J.: Discussion of contribution in enterprise production growth of informatization construction input. Maragement infomoation system (10), 36-38 (2000)

[7] Li, D.L.: China's rural informatization development report 2008. China's publishing house of electronics industry, Beijing (2008)

[8] Liu, S.H.: Information technology in agriculture and rural informatization. China's agricultural science and technology publishing house, Beijing (2005)

[9] Lu, A.X., et al.: Research on rural informationization measuring index system. Agricultural information network (12) (2006)

[10] Mei, F.Q.: Agriculture and rural information service: the diversification, the socialization and networking. China information times (4), 15-22 (2007)

[11] Zhao, C.J.: Rural informationization technology. China's agricultural science and technology publishing house, Beijing (2007)

[12] Zhou, H.: A empirical research on contribution of manufacturing enterprise informatization to the output contribution. Hainan university journals (humanities and social science edition), (3) (2009)

[13] Zhu, Y.P.: Discussion of informatization influence on economic growth. Informatics journal (5), 5-8 (1996) 